\title{
NEGLECTED PRINCIPLES IN THE PURCHASE OF REAL ESTATE BY ONE OF SEVERAL CO-OWNERS
}

The extent to which real estate has become the subject of traffic for gain, in contrast to transactions of many years ago when real estate was the subject of sale and purchase principally from the desire to own a home, a farm, or a business site, has created ambitions so intense that not only is the moral aspect of a "deal" often overlooked, but fixed principles of law as well. In fact, some of these principles have been so generally ignored, that those who are aggrieved by their infraction do not seem even to suspect, or are not advised, that they have any redress. One of such principles is involved in the situation where several persons have a common ownership or interest, and one of them purchases either an outstanding interest or title, or perhaps the entire title, to the exclusion of his coöwners, and it is this principle which forms the present topic. Purchases such as by a commissioner in partition, or a judicial officer conducting a sale, or a guardian of an infant party to an action, ${ }^{1}$ or by an executor, trustee, or similar officer, of the trust property, and involving undebatable fiduciary relations, and in which cases the purchase is held either voidable or absolutely void, ${ }^{2}$ will not be included in this presentation.

PURCHASES BY ONE OF SEVERAL OWNERS.

Sometimes one of several owners in good faith buys in an outstanding title or the entire title, to the exclusion of his coöwners, and sometimes one of such owners buys an outstanding title or the entire title, to squeeze out or "cut off" his coöwners. We shall discuss the aspect of such a purchase by one of several coöwners, where title is held by tenants in common, joint tenants, or in any case where a community of interest exists. While tenants in common may not stand in a strictly fiduciary relation

${ }^{1}$ N. Y. Code Civ. Pro. $\$ 1679$.

${ }^{2}$ See Weintraub v. Siegel, 57 (N. Y.) Misc. Rep. 246, reversing 133 (N. Y.) App. Div. 677, II8 N. Y. Supp. 26I; Terwilliger v. Brown, 44 N. Y. 237; and see Archer v. Archer, 164 (N. Y.) App. Div. 8I, as to purchase by executor with power in trust. 
to each other, in that they may deal with each other like other owners of separate property, their relation is to an extent quasifiduciary, and, as to tenants in common by descent, they occupy a confidential relation toward each other by operation of law, as to the joint property, and the same reciprocal duties are imposed as if a joint trust were created. ${ }^{3}$ Practically the same has been said of tenants in common by devise, ${ }^{4}$ and as our subject is developed, it will be seen that the doctrine now to be discussed has been applied in rather liberal measure to other combined ownerships. A purchase of an outstanding title or interest in property, by a person sustaining certain relations to others interested in the same property, will, at the option of the latter, inure to their benefit. The heirs of one who so purchases stand in no better position than the purchaser. This rule does not apply only strictly to tenants in common, or joint tenants, or others having an equality of interest or estate. The rule is based on a community of interest in a common title, which creates such a relation of trust and confidence between the parties that it would be inequitable to permit one of them to do anything to the prejudice of the other, in reference to the property so situated.5 "Community of interest produces a community of duty, and there is no real difference, on the ground of policy and justice, whether one co-tenant buys up an outstanding incumbrance, or an adverse title, to disseise and expel his co-tenant. It cannot be tolerated, when applied to a common subject, in which the parties had equal concern, and which created a mutual obligation, to deal candidly and benevolently with each other, and to cause no harm to their joint interest." " There may be lack of complete unanimity in enforcing this doctrine, ${ }^{7}$ but as we are now presenting the affirmative of it, we shall follow the preponderant cases in which it has been applied with fairly firm insistence.

${ }^{3} 38$ Cyc. I5; Hinters v. Hinters, II4 Mo. 26; Buchanan v. King's Heirs, 22 Grat. (Va.) 4I4. Cf. Ryason v. Dunton, 164 Ind. 85, 73 N. E. 74.

Enyard v. Enyard, I90 Pa. Ir4.

${ }^{5}$ Rothwell v. Dewees, 67 U. S. 6 I3.

- Van Horne v. Fonda, 5 Johns. Ch. (N. Y.) 388, 407. See also Fulton v. Whitney, 66 N. Y. 548 .

'Streeter v. Schultz, 45 Hun 406, Io N. Y. St. Rep. II5, aff'd. I27 N. Y. 652, referred to in Allen v. Arkenburgh, 2 (N. Y.) App. Div. 457, 74 N. Y. St. Rep. 327, 37 N. Y. Supp. I032, aff'd. I58 N. Y. 697, and explained in Peck v. Peck, IIo N. Y. 74, 17 N. E. 383. 
OTHER INSTANCES OF THE APPLICATION OF THE RULE.

The rule that a purchase by one tenant inures to the benefit of his co-tenants has been applied to many situations. It has been applied to a purchase by the husband of a co-tenant, ${ }^{8}$ to the wife of a co-tenant, presumably because she had an inchoate right of dower, ${ }^{\circ}$ and in another case where the land descended to the husband and children on the death of the wife, it was held that the husband could not, upon a foreclosure sale, purchase the entire title to the exclusion of his children.10 And it has been held that the law not only forbids a person occupying a fiduciary or quasi-fiduciary position from purchasing, but applies to any person interested with another in any subject of property. ${ }^{11}$ "Community of interest in a common title or security implies a mutual obligation not to impair it. It creates such a relation of trust and confidence that it is inequitable to permit one of the parties in interest to do anything to the prejudice of others, and when one of them obtains superior titles or liens he holds them in trust for the benefit of all who share in the common title or security, and who, within a reasonable time after notice of his purchase, contribute their share of his necessary expenditures."12 Even in a case where the court made the concession that it is not a fraud, either actual or constructive, for a joint owner to purchase at a sheriff's sale to enforce payment of taxes, the rule was nevertheless applied that the purchase inured to the coöwners. ${ }^{13}$ There are occasional instances where a person, without authority, assumes the management of property in which others are beneficially interested. In such case, he becomes in equity a trustee by construction for their benefit, and during the continuance of such management is subject to the same rules and remedies as other constructive trustees, and such constructive trustee cannot purchase for his own account. ${ }^{14}$

The cases are not rare where a widow, dissatisfied either with the provision made for her in her late husband's will or with her

${ }^{8}$ Perkins v. Smith, I8 Ky. Law Rep. 509; Rothwell v. Dewees, 67 U. S. 6r3.

- Beaman v. Beaman, 90 Miss. 762.

${ }^{10}$ Wyatt v. Wyatt, 8r Miss. $2 \mathrm{rg}$.

${ }^{11}$ Clements v. Cates, 49 Ark. 242, 245; Richards v. Richards, $3 \mathrm{I} \mathrm{Pa.}$ Super. Ct. 509, 513.

${ }^{12}$ Booker v. Crocker, I32 Fed. 7; McGranighan v. McGranighan, I85 Pa. 340.

${ }^{13}$ Richards v. Richards, 3I Pa. Super. Ct. 509.

${ }^{14}$ Bennett v. Austin, 8I N. Y. 308, 334, 335. 
dower interest or other distributive share in case of death intestate of the husband, seeks to acquire the real property of the estate through purchase on friendly foreclosure or other proceedings, to the exclusion of the devisees or heirs. It is interesting, therefore, to pursue the question whether the rule applies to a widow having a consummate right of dower in land descending to heirs. It may be conceded that the rule applies to a mother of infants whose guardian in socage she is. But the rule seems to be directed against a person owning an interest in the property, irrespective of whether the coöwners are infants or adults. This leads to the question whether a widow, with unassigned dower, may be said to have an interest in the land descending to the heirs. In some states, the widow is a tenant in common with the heirs before assignment of dower. ${ }^{15}$ Other cases either hold or indicate that a widow with unassigned dower is not a tenant in common with the heirs. ${ }^{16}$ And still others in the same jurisdications indicate that she is. ${ }^{17}$ Irrespective of whether she be tenant in common, where a widow has possession of land under a consummate right of dower, of which she could enforce admeasurement, "although this right, while unassigned, did not give her a legal estate in the land, it is now well settled that it was a legal interest and constituted property which was capable in equity of being sold, transferred and mortgaged by the doweress."18 "Although the widow's dower seems never to have been - admeasured, her occupation of the premises may be regarded as putting her practically in the position of a doweress in possession of the one third of the estate to which she was entitled." ${ }^{19}$ So it may be said that remaindermen and the tenant for life are not strictly tenants in common, and yet they are regarded as "equitable co-tenants." 20 In fact, the rule against purchasing for one's own benefit has been specifically applied to a doweress. ${ }^{21}$ And

${ }^{15}$ Woorster v. Hunts Co., 38 Conn. 256. See also Kidwell v. Kidwell, 84 Ind. 224; Centreville Co. v. Jarret, 4 Ind. 213; Grolski v. Kostuski, I79 Ill. 177,53 N. E. 720, 70 Am. St. Rep. 98; McDougal v. Bradford, 80 Tex. 558; Freeman on Co-Tenancy, 2d ed. $\S 108$.

${ }^{10} J$ Jackson v. O'Donaghy, 7 Johns. (N. Y.) 246; McClanahan v. Porter, 1o Mo. 746; Barton v. Reynolds, 81 (N. Y.) Misc. Rep. I5.

${ }^{17}$ See Knolls v. Barnhart, 7I N. Y. 474; Bover v. East, I6I N. Y. 580, 56 N. E. Ir4, 76 Am. St. Rep. 290.

${ }^{29}$ Mutual Life Ins. Co. v. Shipman, Ir9 N. Y. 324, 330, 33I, 24 N. E. I77.

${ }^{10}$ Arthur v. Arthur, 76 (N. Y.) App. Div. 330.

${ }^{\circ}$ Burhands v. Van Zandt, 7 N. Y. 523.

${ }^{21}$ Enyard v. Enyard, 190 Pa. II4. See also Montague v. Selb, I06 III. 49. 
it would seem that the question of infancy, guardianship, or blood relationship, has nothing to do with the situation, ${ }^{22}$ and yet it is not to be denied that some cases probably turn on the point as to the statutory provision in regard to the nature of dower, that is, whether the statute grants an estate to the widow, or merely a right of action to enforce her dower, and also whether, in either case, she was in possesesion, or at least in legal possession, of the property at the time of her attempted exclusive purchase.

RIGHTS OF COÖWNER IN PURCHASE BY ONE OWNER.

Such person so purchasing holds for the benefit of those interested in the property with him, such coöwners being bound, however, to contribute their respective proportions of the consideration paid for the outstanding title or incumbrance, and the coöwners are not barred until after notice of the adverse claim, while the burden of proof is on the one assuming to purchase to the exclusion of his coöwners. ${ }^{23}$ It should be noticed that whereas in the case of a purchase by a trustee, executor, guardian, etc., the sale is either void or voidable, in the case of a purchase such as is now being discussed, while there may be some similarity, yet the purchase is said to inure to the benefit of the coöwners. They may elect to claim the benefit of the purchase or refrain from so electing, or even lose the privilege of electing. ${ }^{24}$ In Buchanan v. King's Heirs, ${ }^{25}$ the general principles applicable to such cases are well set forth. It is there said that a joint tenant, or tenant in common, cannot purchase an outstanding title, for his own benefit, to the exclusion of his co-tenants; that the co-tenant may, within a reasonable time, make his election to claim the benefit, and to contribute to the expense incurred in the purchase of such title; that if he unreasonably delays until there is some change of circumstance he will be held to have abandoned the benefit arising from the purchase; but before such co-tenant can be held to have abandoned his claim, it must

${ }^{22}$ In Knolls v. Barnhart, 7I N. Y. 474, while the court referred to the widow as being the guardian in socage of her minor children, it was coupled with the statement that she was also the doweress, and the case shows that the question of infancy was not the controlling factor.

${ }^{23}$ Buchanan v. King's Heirs, 22 Grat. (Va.) 4I4; Booker v. Crocker, I32 Fed. 7; McGranighan v. McGranighan, I85 Pa. 340; Richards v. Richards, supra; Hinters v. Hinters, II4 Mo. 25.

${ }^{24}$ Ryason v. Dunton, 164 Ind. 85 .

${ }^{25} 22$ Grat. (Va.) 414. 
appear not only that he has been apprised of the purchase, but of the claim set up by his co-tenant, and until then he may assume that the acquisition was made in support of the common title, and the burden of proof is upon the purchasing tenant to show that his co-tenant had notice of the purchase and of the exclusive claim asserted by him. Though one tenant takes the whole profits, or records the deed by which he assumed to purchase as against his co-tenants, such acts are said not to amount to notice that the purchasing tenant claims to have ousted his co-tenant. In another case it was said that the duty to discharge incumbrances rested upon all and payment by one is presumed to have been on behalf of all, and that the interest of all in the property remains notwithstanding the purchase of the legal title by one, and the amount necessary for the preservation of the property is chargeable against it and may be enforced in an equitable proceeding. ${ }^{2 B}$ And if one tenant may not buy in an outstanding title, much less may he buy in a title that cuts off altogether the title under which he and his co-tenants hold. ${ }^{27}$

PURCHASES AT PUBLIC SALES.

The Supreme Court of the United States while recognizing the principle that there is such a community of interest between those who hold a common title as to forbid one such co-tenant from acquiring any benefit from the acquisition of an outstanding superior title, and that a court of equity upon timely application will convert such a purchasing tenant into a trustee for the common benefit, declined to extend the doctrine to purchases at bona fide public sales, saying: "But it is plain that the principle which turns a co-tenant into a trustee who buys for himself a hostile outstanding title, can have no proper application to a public sale of the common property, either under legal process or a power in a trust deed. In such a situation, the sale not being in any wise the result of collusion nor subject to the control of such a bidder, he is as free, all deceit and fraud out of the way, as any one of the general public."'28 Other cases apply the doctrine even to public sales. ${ }^{29}$ But it is frequently the case that the purchasing

${ }^{20}$ Richards v. Richards, 3I Pa. Stuper. Ct. 509, 5 I3.

${ }^{27}$ Swineburne v. Swineburne, 28 N. Y. 568.

${ }^{2}$ Starkweather v. Jenner, 216 U. S. 524.

${ }^{20}$ See Ryason v. Dunton, supra; Ladd v. Kuhn, 27 Ind. App. 535; Beaman v. Beaman, 90 Miss. 762; Wyatt v. Wyatt, 8r Miss. 219; Knolls v. Barnhart, 7 I N. Y. 474; Dec. Dig., Vol. I9, p. I48; Cent. Dig., Vol. 45, col. 2675 . 
tenant designs to bring about a public sale under foreclosure or otherwise, for the very purpose of bidding in the property for his own benefit, and in such cases the principle would undoubtedly apply. ${ }^{30}$ Judgments and decrees for the sale of real property usually contain a provision granting formal leave to purchase to the parties to the action. Such leave seems to be of doubtful effect as to equities which may exist between the parties. It has been said that where the rights and equities of a plaintiff, as between him and his trustees, are in no form or manner before the court, or involved in the action, it is not "the purpose of the ordinary provision allowing any party to the action to purchase to affect equities which may exist between the purchaser and any other person for whose benefit the purchase may be deemed to have been made. Such a provision in foreclosure cases is usually inserted for the purpose of removing any doubt as to the right of the complainant, who conducts the suit and the sale, to become the purchaser. If the purchaser; though a party to the action, is acting in a fiduciary capacity arising outside of the relation of mortgagor and mortgagee, his liability to his cestui que trust cannot be affected by such a provision, nor by the order confirming the sale." 31 In some cases, as under the practice in partition actions in some states, the sale is first reported to the court, then confirmed, and a conveyance is then authorized, so that the court knows who the purchaser is before the sale is confirmed, and it may be argued that such sale is made and confirmed with full knowledge by the court as to the identity and situation of the purchaser. " "But where the trustee has an interest to protect by bidding at the sale of the trust property, and he makes special application to the court for permission to bid, which, upon the hearing of all the parties interested is granted by the court, then he can make a purchase which is valid and binding upon all the parties interested, and under which he can obtain a perfect title." 33

BRookLYN, N. Y.

FRED L. Gross.

\footnotetext{
${ }^{30}$ See Carpenter v. Carpenter, I3I N. Y. IOI, 29 N. E. IOI3; Ream v. Robinson, I28 Mich. 92; Collins v. Collins, 36 N. Y. St. Rep. 59r, affirmed I3I N. Y. 648, 30 N. E. 863 .

${ }^{31}$ Fulton v. Whitney, 66 N. Y. 548; Scholle v. Scholle, ror N. Y. 167, 4 N. E. 334; Bennett v. Austin, 8I N. Y. 308, 327.

${ }^{32}$ See Corbin v. Baker, I67 N. Y. I28, 60 N. E. 332.

${ }^{33}$ Scholle v. Scholle, Ior N. Y. I67, 4 N. E. 334, and authorities there cited.
} 